University of Montana

ScholarWorks at University of Montana

Ecosystem and Conservation Sciences Faculty

Publications

Ecosystem and Conservation Sciences

$7-2011$

\title{
Satellite Finds Highest Land Skin Temperatures on Earth
}

David J. Mildrexler

Maosheng Zhao

Steven W. Running

University of Montana - Missoula, steven.running@umontana.edu

Follow this and additional works at: https://scholarworks.umt.edu/decs_pubs

Part of the Terrestrial and Aquatic Ecology Commons

Let us know how access to this document benefits you.

\section{Recommended Citation}

David J. Mildrexler, Maosheng Zhao, and Steven W. Running, 2011: Satellite Finds Highest Land Skin Temperatures on Earth. Bull. Amer. Meteor. Soc., 92, 855-860.

This Article is brought to you for free and open access by the Ecosystem and Conservation Sciences at ScholarWorks at University of Montana. It has been accepted for inclusion in Ecosystem and Conservation Sciences Faculty Publications by an authorized administrator of ScholarWorks at University of Montana. For more information, please contact scholarworks@mso.umt.edu. 


\section{Satellite Finds Highest Land Skin Temperatures on Earth}

by David J. Mildrexler, Maosheng Zhao, and Steven W. Running

$\mathrm{T}$ he location of the hottest spot on Earth has undoubtedly been an interesting curiosity for centuries. Even with the advent of the instrumental temperature record around the year 1850 , the location of the hottest spot on Earth has continued to be the subject of debate and controversy. In 1913, the weather station at Furnace Creek in Death Valley National Park, California, measured an air temperature of $56.7^{\circ} \mathrm{C}\left(134.1^{\circ} \mathrm{F}\right)$ and claimed the title of "hottest place on Earth." Nine years later in El Azizia, Libya, an air temperature of $57.8^{\circ} \mathrm{C}\left(136^{\circ} \mathrm{F}\right)$ was recorded on land owned by an Italian farmer and the title of the "hottest place on Earth" moved from the United States to Libya. The 1922 air temperature measurement from El Azizia has never been surpassed.

In reality, finding the hottest spot on Earth based on scattered site-based air temperature measurements is a limited approach due to the poor spatial coverage of the instruments where measurements are taken compared with Earth's expansive barren deserts where the hottest conditions occur. The World Meteorological Organization (WMO) has approximately 11,119 weather stations on Earth's land surface collecting surface temperature observations (ftp://ftp.ncdc.noaa.gov/pub/data/gsod/20l0). When compared to the 144.68 million $\mathrm{km}^{2}$ of land surface, that's one station every $13,012 \mathrm{~km}^{2}$. The Earth's hot deserts, such as the Sahara, the Gobi, the Sonoran, and the Lut, are climatically harsh and so remote that

AfFiliations: Mildrexler, ZhaO, and RunNing-Numerical Terradynamic Simulation Group, Dept. of Ecosystem and Conservation Sciences, University of Montana, Missoula, Montana CORRESPONDING AUTHOR: David Mildrexler, Numerical Terradynamic Simulation Group, Dept. of Ecosystem and Conservation Sciences, University of Montana, Missoula, MT 59812 E-mail: drexler@ntsg.umt.edu

DOI:10.II75/20IIBAMS3067.I

(C)20II American Meteorological Society access for routine measurements and maintenance of a weather station is impractical. The majority of Earth's potentially hottest spots are simply not being directly measured by ground-based instruments. Satellites provide a continuous view of Earth's surface, allowing equal observation of the most remote areas and the most accessible. However, satellites do not measure the near-surface air temperature; instead they measure the radiometric surface temperature, or skin temperature, a different physical parameter.

\section{RADIOMETRIC LAND SURFACE TEM- PERATURE AND AIR TEMPERATURE.}

Around the same time that the Death Valley record air temperature was measured, an analysis of the temperature conditions of air and soil was conducted in the desert near Tucson, Arizona. At 1:00 p.m. LT on 21 June 1915 , a maximum soil temperature of $71.5^{\circ} \mathrm{C}$ $\left(160.7^{\circ} \mathrm{F}\right)$ was measured $0.4 \mathrm{~cm}$ below the soil surface. The corresponding air temperature measured $4 \mathrm{ft}$ above the ground was $42.5^{\circ} \mathrm{C}\left(108.5^{\circ} \mathrm{F}\right)$. Other studies that have observed extreme maximum surface temperatures and air temperatures near the time of the observed surface temperature have found differences of even greater magnitude.

Physical considerations indicate that the most extreme maximum temperatures will occur at baresoil surfaces under full solar illumination and low wind speed, where the soil is dry and has a very low albedo and low thermal conductivity. The satellitebased land surface temperature (LST) measures the radiation emitted by the top of the land surface (i.e., radiometric LST) and can be likened to skin temperature, or the temperature a person would feel if touching the land surface. It measures directly where the highest temperatures on Earth's surface manifest, on the ground. By comparison, standard weather station air temperature is measured $1.5 \mathrm{~m}$ above the ground level with sensors protected from radiation and adequately ventilated. Because air is such a poor heat conductor, the radiometric LST in midsummer 


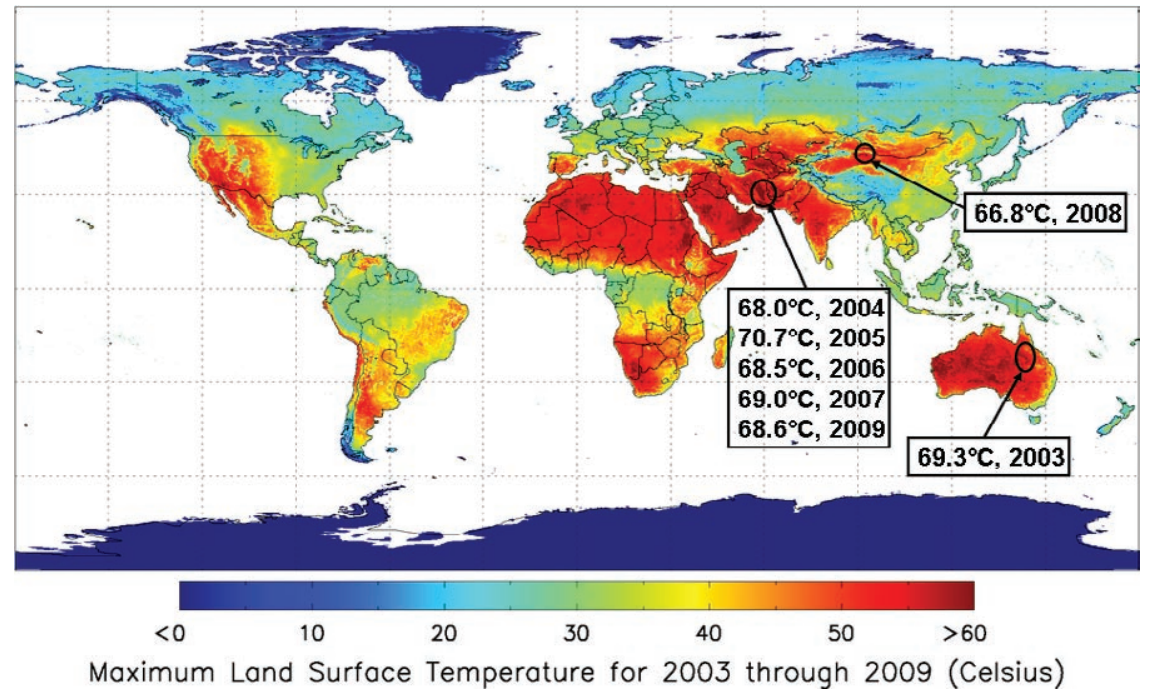

FIG. I. Global maps of annual maximum LST based on high-resolution satellite data provide a powerful tool for continuously monitoring the most extreme LSTs. The highest LSTs (in red) are found in Earth's deserts. Grasslands, shrublands, and savannas (in orange and yellow) transition into the cooler LSTs of forests (in green and light blue). Dark blue areas are predominantly covered with year-round ice and include some high-elevation mountain ranges.
The Aqua/MODIS Climate Model Grid (CMG) data used to create global maps of annual maximum LST have a spatial resolution of $0.05^{\circ}$ (approximately $5.6 \mathrm{~km}$ at the equator) and is aggregated from 1-km LST data. Due to this averaging, the Aqua/MODIS LST is likely underestimating the most extreme maximum surface temperatures, and surface energy balance simulations indicate that conditions exist for surface temperatures between $90^{\circ}$ and $100^{\circ} \mathrm{C}$.

With an automated algorithm based on the $0.05^{\circ}$-resolution Aqua/MODIS LST data, we have been tracking the maximum LST globally and pinpointing the location of the can be $30^{\circ}-50^{\circ} \mathrm{C}$ higher than the air temperature. Imagine the searing heat of beach sand (i.e., LST) on a hot summer day, when standing in shade or water is the only way to avoid burning your feet, compared to the air temperature $1.5 \mathrm{~m}$ above the sand.

THE AQUA/MODIS INSTRUMENT AND LST DATA. As part of NASA's Earth Observing System (EOS), two MODIS instruments have been launched to provide information for global studies of atmosphere, land, and ocean processes. The first instrument was launched on 18 December 1999 on the morning platform called Terra, and the second was launched on 4 May 2002 on the afternoon platform called Aqua. The strengths of the MODIS instruments are global coverage, high geolocation accuracy, high radiometric resolution, and accurate calibration in the visible, near-infrared, and thermal bands. The MODIS LST products have been validated within $1 \mathrm{~K}$ at multiple validation sites in a relatively wide range of surface and atmospheric conditions. Locations where the most extreme maximum surface temperatures occur can have greater uncertainty $(\approx 2 \mathrm{~K})$ due to saturation of the thermal channels used to derive the surface emissivity. We use LST from the Aqua/MODIS sensor because it has the additional advantage of an afternoon overpass (1:30 p.m. LT each day) that retrieves LSTs close to the maximum daily temperature of the land surface. hottest spot on Earth since 2003. The highest LST recorded at each grid cell during any 8-day period over an annual cycle is extracted and combined into one image. It is well known that the highest surface temperatures on Earth occur in bare-soil environments. Therefore, to reveal the hottest spot on Earth we focused on barren areas and sparsely vegetated open shrublands. This eliminates wildfire in vegetated areas from being mistaken for an extremely high LST, a problem that is also minimized by the integration of $1-\mathrm{km}$ pixels across the CMG gridcell. Next, we selectively screened out all pixels on the global land surface below an incrementally increased threshold until, finally, only one place remained. Here we present the hottest spot on Earth annually from 2003 to 2009 (Fig. 1).

THE HOTTEST SPOT ON EARTH. The Lut Desert, located in southeast Iran, has long been regarded as one of the hottest places on Earth. Numerous studies have examined the relationship between the expression of severe thermal temperature across this hyperarid landscape and the unique natural physical characteristics of the Lut, such as the wind-sculpted megayardangs and the vast areas of closely packed rock fragments known as desert pavement. The Lut Desert was determined to be the hottest spot on Earth in two of three years previously evaluated with the Aqua/MODIS satellite LST data. 
Here we found that the Lut Desert had the highest surface temperature on Earth in $2004\left(68.0^{\circ} \mathrm{C} ; 154.4^{\circ} \mathrm{F}\right)$, $2005\left(70.7^{\circ} \mathrm{C} ; 159.3^{\circ} \mathrm{F}\right)$, $2006\left(68.5^{\circ} \mathrm{C} ; 155.3^{\circ} \mathrm{F}\right), 2007$ $\left(69.0^{\circ} \mathrm{C} ; 156.2^{\circ} \mathrm{F}\right)$, and 2009 $\left(68.6^{\circ} \mathrm{C} ; 155.5^{\circ} \mathrm{F}\right)$-five of the seven years analyzed in this study. The Lut is the only place on Earth to have a surface temperature above $70^{\circ} \mathrm{C}\left(158^{\circ} \mathrm{F}\right)$, and it regularly has the largest contiguous area of surface temperatures above $65^{\circ} \mathrm{C}$ of anywhere on Earth (Fig. 2). For comparison, the highest LST measured at the pixel corresponding to the location of the Furnace Creek
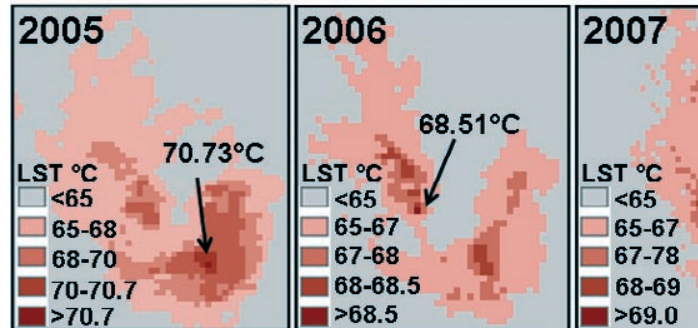
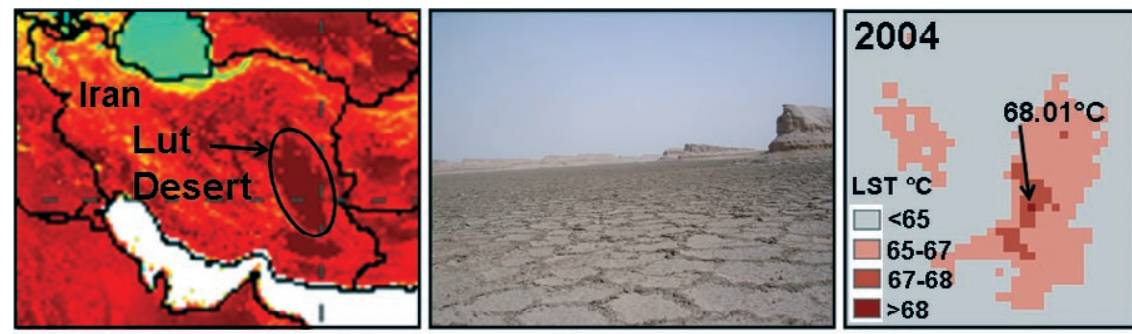

FIG. 2. The Lut Desert has an areal extent of about $80,000 \mathrm{~km}^{2}$ and contains several geomorphic distinctions, such as the highest megayardangs on Earth. Large areas of the Lut Desert regularly exceed $65.0^{\circ} \mathrm{C}$, and the hottest spot on Earth was detected in the Lut five out of seven years. (Photograph by Jafar Sabouri.) weather station in Death

Valley from 2003 to 2009 was $62.7^{\circ} \mathrm{C}\left(144.9^{\circ} \mathrm{F}\right)$ in $2005,8^{\circ} \mathrm{C}$ cooler than the Lut Desert $\left(70.7^{\circ} \mathrm{C}\right)$.

In 2003 , a scorching temperature of $69.3^{\circ} \mathrm{C}$ $\left(156.7^{\circ} \mathrm{F}\right)$, the second highest temperature of the $7-\mathrm{yr}$ dataset, was detected in the province of Queensland, Australia. Australia is the driest inhabited continent on Earth, with vast arid lands where annual maximum LSTs routinely exceed $60^{\circ} \mathrm{C}$. Since 1995 , a large region of Australia has been gripped by the most severe drought in living memory, the so-called "Big Dry." In 2002 and 2003, the drought conditions were especially severe due to the 2002 El Niño-Southern Oscillation (ENSO). Record-low rainfall coupled with high evaporation rates due to widespread maximum temperature anomalies resulted in extreme conditions in southeast and northeast Australia, including the highest LST on Earth.

In 2008 , the highest LST on Earth of $66.8^{\circ} \mathrm{C}$ $\left(152.2^{\circ} \mathrm{F}\right)$ was recorded in the Turpan Basin of the Xinjiang Uygur Autonomous Region of northwest China. Flaming Mountain, a series of stone peaks that stretches approximately $100 \mathrm{~km}$ across the Turpan Basin and is dominated by dark red sandstone that heats up to extremely high temperatures in the midafternoon sun, has long been regarded as the hottest place in China. At midday in the summer, as the blazing hot air currents rise off the mountain, Flaming Mountain is said to look like a huge flying red dragon setting off fires.
A century ago, few could have imagined that the location of the hottest spot on Earth varied between different continents over a relatively short time period. This analysis shows just that, indicating that in addition to site physical characteristics, climatic variations play a role in where the hottest spot on Earth will be in a given year.

\section{GLOBAL DISTRIBUTION OF ANNUAL MAXIMUM COMPOSITE LST. Annual maxi-} mum LST is directly related to vegetation density, and changes in surface temperature resulting from land-cover changes comprise an important aspect of climate change that needs to be better quantified. Spatially continuous global maps of annual maximum LST provide the means to visually assess the patterns of the highest temperatures across both large-scale natural vegetation density gradients-such as the transition from the tropical rain forests of the Congo to the Sahara Desert-and relatively small-scale landcover changes due to irrigation in a semiarid desert. Annual histograms of the maximum LST for each $0.05^{\circ}$ pixel illustrate their distribution and frequency across the global land area (Fig. 3). Based on seven years of data, the histograms show low interannual variability and display a trimodal distribution with three distinct spikes. The maximum LST spike between $50^{\circ}$ and $60^{\circ} \mathrm{C}$ represents Earth's hot deserts. These barren or sparsely vegetated areas routinely have high LSTs in 
midsummer. The central spike, ranging between $20^{\circ}$ and $35^{\circ} \mathrm{C}$, is primarily due to forests, and highlights their important role in regulating maximum LST across Earth's surface through transpirational cooling. The lowest temperature spike, between $-30^{\circ}$ and $0^{\circ} \mathrm{C}$, represents Earth's ice-covered polar regions. Savannas and grasslands tend to occupy the $35^{\circ}-50^{\circ} \mathrm{C}$ range, with grasslands exceeding $50^{\circ} \mathrm{C}$ in very arid areas. Agricultural areas such as croplands occupy a broad maximum LST range $\left(\sim 25^{\circ}-50^{\circ} \mathrm{C}\right)$ due to sustained direct human interaction.

The cryosphere is undergoing significant transformations due to climate change, but large uncertainties remain in part due to the limited monitoring of the large ice mass by surface-based measurements. Tracking the annual maximum LST histogram for ice-covered regions might provide a new way to detect large-scale ice-warming trends. With continuous spatial coverage, maximum LST has the additional advantage of occurring in clear-sky conditions, whereas minimum LST occurs in the winter, when cloud cover is common. Skin temperature cannot be observed in cloudy conditions, making a continuous global map of minimum LST unreliable. Ice surface emissivities have higher uncertainties than areas covered by vegetation,

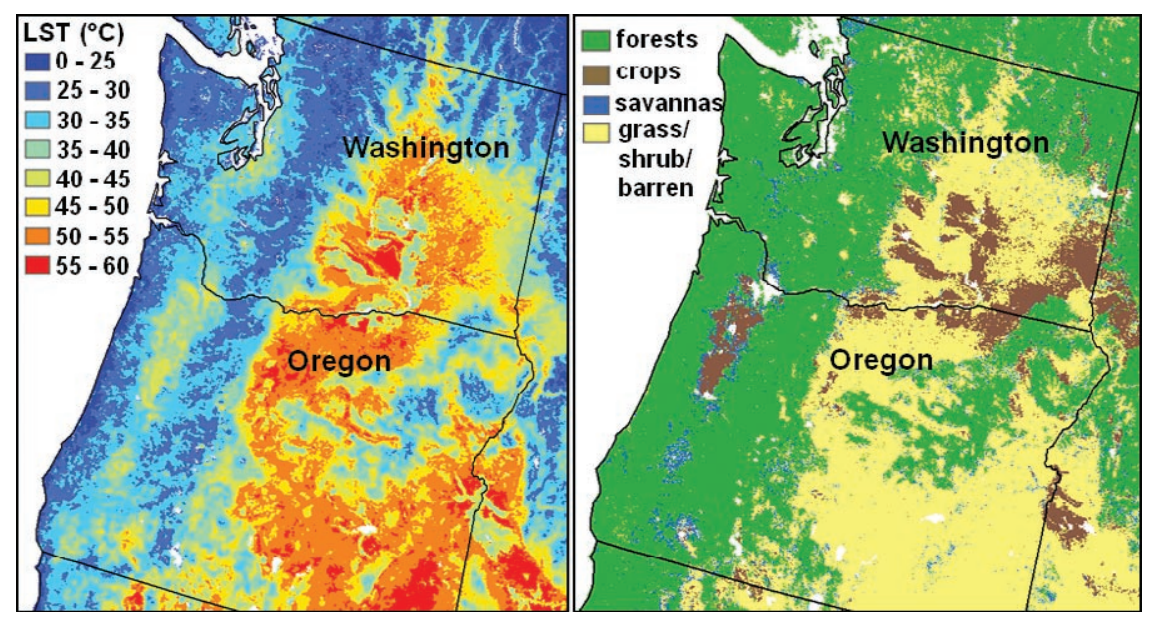

FIg. 4. The expression of annual maximum LST across the Pacific Northwest shows strong association with land-cover type, and spatially illustrates the histogram distribution shown in Fig. 3 for forests, savannas, croplands, grasslands, shrublands, and barren areas. but smaller than some areas of bare soils (Zhengming Wan, personal communication, 19 January 2007). In Antarctica, the highest annual LSTs are incredibly cold $\left(-30^{\circ}-0^{\circ} \mathrm{C}\right)$. For comparison, the highest air temperature ever recorded at the Vostok Research Station in Antarctica is $-12.2^{\circ} \mathrm{C}$ on 11 January 2002 . As ice sheets are exposed to warmer conditions, pools of water accumulate on the surface, and retreating ice exposes bare ground. These changes result in a darker, less reflective surface with higher surface temperatures and, over time, commensurate shifts in the annual maximum LST histogram for ice-covered regions.

The expression of maximum LST and its close association with a given area's land-cover type is spatially examined across the Pacific Northwest (Fig. 4). Forests show a very close association with maximum LSTs in the $20^{\circ}-35^{\circ} \mathrm{C}$ range on both the wet, west side of Oregon and Washington and on the 
relatively dry east side. Savannas tend to occupy the edge of forested areas and have a maximum LST range between $30^{\circ}$ and $45^{\circ} \mathrm{C}$. Croplands show strong association with maximum LST between $35^{\circ}$ and $50^{\circ} \mathrm{C}$. The effect of irrigation lowering the maximum LST relative to the surrounding nonirrigated native grass and shrub areas is visible in eastern Washington and Oregon. Arid grasslands, sparse shrublands, and barren areas show a strong association with maximum LSTs between $45^{\circ}$ and $60^{\circ} \mathrm{C}$. Human-induced land-use changes (e.g., deforestation, degradation of semiarid areas, clearing for agriculture, changes in the irrigated land area, afforestation, and widespread urbanization), coupled with changes in large-scale natural disturbances (e.g., wildfires, hurricanes, insect outbreaks, droughts), will alter these surface temperatures and the distribution of the annual maximum LST histogram. Long-term perturbations of the local land-surface energy balance resulting from disturbances like wildfire are clearly distinguishable from the adjacent undisturbed areas. Annual maximum composite LST data coupled with a vegetation index is now used to provide large-scale, automated disturbance mapping.

As more years of data accumulate, the dataset presented in Fig. 3 could become a new type of integrative global change measurement. The annual maximum LST histogram merges into a single metric important biophysical and biogeographical factors of the Earth system that are usually measured individually. These contributing factors can include 1) intensification of extreme maximum surface temperatures; 2 ) changes in land cover; 3) changes in albedo; 4) surface-atmosphere energy fluxes; 5) changes in ecosystem disturbance regimes; 6) air temperature; and 7) atmospheric aerosol concentrations. However the potential for change in each of these factors varies tremendously and unpredictably in time and space. This integrative measurement is strongly influenced by the biogeographic patterns of Earth's ecosystems, providing a unique comparative view of the planet every year such that changes in any component of the trimodal distribution are detectable. For example, changes that result in the lower tail of the distribution shifting from $-30^{\circ}$ to $-20^{\circ} \mathrm{C}$ would indicate a major change in the cryosphere. Likewise, if we see the central spike for forests becoming progressively smaller and the spike that represents deserts becoming larger, further research could focus on determining the causality. This potentially valuable annual maximum LST metric is automated and easy to produce for continued global monitoring of the highest temperatures on Earth.

ACKNOWLEDGMENTS. This effort was sponsored by the NASA Earth Sciences Division MODIS Project (NNX08AG87A).

\section{FOR FURTHER READING}

Alavipanah, S. K., A. A. Shamsipour, and R. Amiri, 2007: A study of the relationship among temperatures of surface features and its application in remote sensing study of Lut desert. Biaban, 12, 85-97.

Azizi, G., S. K. Alavipanah, N. Goodarzi, and M. Kazemi, 2007: An estimation of the temperature of Lut desert using MODIS sensor data. Biaban, 12, 7-15.

Bonan, G. B., 2008: Forests and climate change: Forcings, feedbacks, and the climate benefits of forests. Science, 320, 1444-1449.

Cerveny, R. S., J. Lawrimore, R. Edwards, and C. Landsea, 2007: Extreme weather records: Compilation, adjudication, and publication. Bull. Amer. Meteor. Soc., 88, 853-860.

Garratt, J. R., 1992: Extreme maximum land surface temperatures. J. Appl. Meteor., 31, 1096-1105.

Jin, M., and R. E. Dickinson, 2010: Land surface skin temperature climatology: Benefitting from the strengths of satellite observations. Environ. Res. Lett., 5, 1-13.

Lemke, P., and Coauthors, 2007: Observations: Changes in snow, ice and frozen ground. Climate Change 2007: The Physical Science Basis. Contribution of Working Group I to the Fourth Assessment Report of the Intergovernmental Panel on Climate Change, S. Solomon et al., Eds., Cambridge University Press, 339-378.

Mildrexler, D. J., M. Zhao, and S. W. Running, 2006: Where are the hottest spots on Earth? Eos Transactions, 87, 461-467.

,$- \ldots$, and — 2009: Testing a MODIS global disturbance index across North America. Remote Sens. Environ., 113, 2103-2117.

Nemani, R. R., S. W. Running, R. A. Pielke, and T. N. Chase, 1996: Global vegetation changes from coarse resolution satellite data. J. Geophys. Res., 101, 7157-7162.

Peel, R. F., 1974: Insolation weathering: Some measurements of diurnal temperature changes in exposed rocks in the Tibetsi region, central Sahara. Z. Geomorph. N. F., Suppl. Bd, 21, 19-28. 
Prata, A. J., 2000: Global distribution of maximum land surface temperature inferred from satellites. Csiro Atmospheric Research Technical Paper No. 46. [Available online at www.eoc.csiro.au/associates/ aatsr/lst_atlas.pdf.]

Roof, S., and C. Callagan, 2003: The climate of Death Valley, California. Bull. Amer. Meteor. Soc., 84, 1725-1739.

Running, S. W., 2008: Ecosystem disturbance, carbon and climate. Science, 321, 652-653.
Sinclair, J. G., 1922: Temperatures of the soil and air in a desert. Mon. Wea. Rev., 50, 142-144.

Ummenhofer, C. C., M. H. England, P. C. McIntosh, G. A. Meyers, M. J. Pook, J. S. Risbey, A. Sen Gupta, and A. S. Taschetto, 2009: What causes southeast Australia's worst droughts? Geophys. Res. Lett., 36, 1-5.

Wan, Z., Y. Zhang, Q. Zhang, and Z.-L. Li, 2004: Quality assessment and validation of the MODIS global land surface temperature. Int. J. Remote Sens., 25, 261-274. 